\title{
The truth about abuse?: A comparative approach to inquiry narratives on historical institutional child abuse
}

Johanna Sköld

\section{Linköping University Post Print}

\section{Tweet}

N.B.: When citing this work, cite the original article.

This is an electronic version of an article published in:

Johanna Sköld, The truth about abuse?: A comparative approach to inquiry narratives on historical institutional child abuse, 2016, History of Education, (45), 4, 492-509.

History of Education is available online at informaworldTM:

http://dx.doi.org/10.1080/0046760X.2016.1177607

Copyright: Taylor \& Francis (Routledge): SSH Titles

http://www.routledge.com/

Postprint available at: Linköping University Electronic Press

http://urn.kb.se/resolve?urn=urn:nbn:se:liu:diva-128620 


\title{
The Truth about Abuse? A Comparative Approach to Inquiry Narratives on Historical Institutional Child Abuse
}

\section{Johanna Sköld}

\author{
History of Education, vol 45, issue 4, 2016
}

\begin{abstract}
In recent decades, history of childhood and history of education have gained status as political concerns through the establishment of numerous truth commissions and inquiries into historical institutional child abuse. The article discusses the methodological and ethical dilemmas that arise when writing the history of abused children with the objective of both recognising and redressing the victims as well as offering an account of "what really happened'. Comparing how inquiry commissions in Ireland, Sweden and Denmark evaluate and approach victims' oral testimonies and written records from child welfare agencies, the article explores the acts of balancing between different epistemological approaches to the concept of "truth". The results suggest that while inquiries have to address and convince several audiences simultaneously, empiricist positivist methods of inquiry have dominated the approaches to "truth". However, this approach has not been without ambivalence, and there are examples of constructivist approaches as well.
\end{abstract}

Keywords: historical institutional child abuse, truth commission, inquiry, truth, ethics 


\section{Introduction}

In recent decades, history of childhood and history of education have gained status as political concerns through the establishment of numerous truth commissions and inquiries into historical institutional child abuse. ${ }^{1}$ This ethically sensitive topic, demanding several cautions from investigators and historians alike, has become the focus of political attention in at least 19 countries, mainly in Europe but also Australia, New Zealand and Canada. The issue of historical institutional child abuse has been brought to the fore through care leavers' demands for recognition, reparation and justice - sometimes resulting in major class action lawsuits, and/or widespread compelling media coverage, that have eventually forced governments and other responsible bodies to take action. A common response has been to launch an inquiry investigating the past through interviews or oral hearings with victims, sometimes preceding or following an official apology by the government or representatives of the care providers and financial redress schemes. ${ }^{2}$

The reports from these inquiries form new kinds of history narratives about childhood in general and out-of-home care in particular. This article aims to critically analyse these narratives, with the objective to ask what we - as professional historians of children, childhood and education - can learn from the methods and ethical considerations issued in the inquiry reports? This article explores how these particular history narratives are shaped by the epistemological, methodological and ethical dilemmas arising from the dual objective of investigating as well as recognising the victims and offering them justice for past atrocities within out-of-home care facilities for children. Recognition has been defined as a reciprocal relationship between humans that is necessary for subjectivity. For Axel Honneth, struggling

\footnotetext{
${ }^{1}$ Kathleen Daly has identified that the concept of institutional abuse seems to refer to different contexts, depending on whether the focus is on historical or contemporary institutional abuse. Literature on historical institutional child abuse mainly deals with abuse at residential institutions, whereas contemporary institutional abuse includes foster care. See Kathleen Daly, Redressing Institutional Abuse of Children (Basingstoke: Palgrave Macmillan, 2014): 18-19. In this article, 'historical institutional abuse' includes foster care. Currently available literature on historical abuse has failed to include foster care simply because few inquiries have paid attention to this kind of out-of-home care; but this is likely to change in the future. The Swedish Commission to Inquire into Child Abuse and Neglect in Institutions and Foster Homes, explored in this article, is just one example.

${ }^{2}$ Johanna Sköld, 'Historical Abuse-A Contemporary Issue: Compiling Inquiries into Abuse and Neglect of Children in Out-of-Home Care Worldwide' Journal of Scandinavian Studies in Criminology and Crime Prevention 14, sup1 (2013): 5-23; Daly, Redressing Institutional Abuse of Children.
} 
for recognition is a social action that can be emotionally motivated by suffering and the experience of being disrespected. ${ }^{3}$

The objective of recognition and justice distinguishes the inquiry reports from traditional ways of 'doing' history of childhood or history of education; even if historians of childhood and education who are interested in memory have provided children a voice and representation in history. ${ }^{4}$ The objective of recognition and justice, I argue, means that the reports have to address and satisfy certain audiences, which in turn affects how the reports are narrated..$^{5}$

In contrast to many historians who publish for an academic audience, truth and inquiry commissions write their reports with other, sometimes conflicting, audiences in mind: victims, governments, former care providers, legal professionals and the wider general public. For some victims the suffering from institutional abuse is an ongoing trauma - in the words of Berber Bevernage, 'a persisting "past"" 6 - with consequences in the present and future. An inquiry can at best recognise their suffering, acknowledge and record the abuse and harm caused to them and identify who was responsible, consequently aiming at justice by letting victims 'tell their truths'. However, as Ronald Niezen stresses in his book about the Canadian Truth and Reconciliation Commission on Indian Residential Schools, this justice goal is not accomplished unless the 'suffering' is acknowledged by a broad general public: 'Public sympathy has become the interim goal, the indispensable provisional prize on the way to the real prize of restitution, the central source of energy behind campaigns of justice. ${ }^{7}$ In addition, Niezen concludes, for the public to be persuaded the message has to be repeated in a creative $w^{8}{ }^{8}$, which coincides with the fact that for some, albeit not all victims, historical institutional abuse is a never-ending story. By contrast, governments or care providers want to

\footnotetext{
${ }^{3}$ Axel Honneth, Struggle for Recognition: The Moral Grammar of Social Conflicts (Cambridge: Polity Press, 1995), 138.

${ }^{4}$ See for example Stephen Humphries, Hooligans or Rebels? An Oral History of Working-Class Childhood and Youth 1889-1939 (Oxford: Blackwell, 1995); Anna Davin, Growing up Poor: Home, School and Street in London 1870-1914 (London: Rivers Oram Press, 1996); Neil Sutherland, Growing Up: Childhood in English Canada from the Great War to the Age of Television (Toronto, Buffalo: University of Toronto Press, 1997, 2002).

${ }^{5}$ See also Onur Bakiner, 'One Truth among Others? Truth Commissions' Struggle for Truth and Memory' Memory Studies 8, no. 3 (2015): 346-360.

${ }^{6}$ Berber Bevernage, History, Memory and State-Sponsored Violence: Time and Justice (New York: Routledge, 2012), 5 .

${ }^{7}$ Ronald Niezen, Truth \& Indignation: Canada's Truth and Reconciliation Commission on Indian Residential Schools (Toronto: University of Toronto Press, 2013), 14.

${ }^{8}$ Ibid., 13.
} 
investigate what happened in the past and move on. ${ }^{9}$ It is in the intersection of these ambitions and expectations that investigators have to navigate when 'doing' the history narrative of institutional child abuse.

I myself am familiar with this dilemma of addressing conflicting audiences while conducting the dual objective of investigating and recognising, since I was a member of the secretariat for the Swedish Commission to Inquire into Child Abuse and Neglect in Institutions and Foster Homes, operating 2006-2011. However, I am also a childhood historian, interested in the wider history of out-of-home care and why the long known ${ }^{10}$ abuse within such settings of 'care' has only in recent decades come to be identified as human rights violations constituting a new branch within the field of restorative or transitional justice, and subsequently how this politicised concern about historical institutional abuse shapes narratives of the history of childhood and history of education. ${ }^{11}$ As Hayden White, Frank Ankersmit, Alun Munslow, and other deconstructionist philosophers of history have required, historians should re-think their own acts of 'doing' history, basically by being transparent regarding how we narrate and emplot the subjects we represent. Still this is, at least according to Munslow, a quite unusual operation for historians. ${ }^{12}$ However, deconstructing historical narratives produced outside academia, like in truth commissions or other kinds of public memory-making, has become the object of enquiry for historians and other scholars alike. ${ }^{13}$

\footnotetext{
${ }^{9}$ Nell Musgrove, 'The Role and Importance of History', in Apologies and the Legacy of Abuse of Children in 'Care', eds. Johanna Sköld and Shurlee Swain (Basingstoke: Palgrave Macmillan, 2015), 154; Barbara Adkins and Donna Hancox, "The Role of Internet in the Testimony: the Case of the "Forgotten Australians" Media, Culture \& Society 36, no. 8 (2014):1164.

${ }^{10}$ In her compilation of 19 Canadian and Australian cases of redress for institutional child abuse, Kathleen Daly identified that it took on average 37 years for governments and church authorities to respond to complaints of child abuse at institutions they were responsible for. The child victims were not believed until they came forward as adult survivors in a time and context in which historical institutional abuse had been identified as a social problem. Daly, Redressing Institutional Abuse of Children, 104-105.

${ }^{11}$ Sköld, 'Historical Abuse-A Contemporary Issue'; Stephen Winter, Transitional Justice in Established Democracies: A Political Theory (Basingstoke: Palgrave Macmillan 2014)].

${ }^{12}$ Hayden White, The Content of the Form: Narrative Discourse and Historical Representation (Baltimore: Johns Hopkins Univ. Press, 1987); Robert John Parkes, 'Postmodernism, Historical Denial, and History Education: What Frank Ankersmit Can Offer to History Didactics' Nordidactica, no.2 (2013): 20-36; Alun Munslow, 'Introduction', in Authoring the Past: Writing and Rethinking History, ed. Alun Munslow (London and New York: Routledge 2013), 5.

${ }^{13}$ A brief overview of this research is presented in Klaus Neumann, 'Historians and the yearning for historical justice', Rethinking History 18, no. 2 (2014): 150-151. Studies approaching the narrative construction of inquiries into historical child abuse include Brian Corby, Alan Doig and Vicky Roberts, Public Inquiries into Residential Abuse of Children (London: Jessica Kingsley, 2001); Gillian Whitlock, 'In The Second Person: Narrative Transactions In Stolen Generations Testimony’ Biography 24, no.1 (2001): 197-214; Rosanne Kennedy, "Stolen Generations Testimony: Trauma, Historiography, and the Question of "Truth" in The Oral History Reader, eds. Robert Perks and Alistair Thomson (London and New York: Routledge, 2006): 506-520; John Murphy, 'Memory, Identity and Public Narrative: Composing a Life-Story after Leaving Institutional Care, Victoria, 1945-83' Cultural \& Social History 7, no. 3 (2010): 297-314; Paul Michel Garrett, 'A “Catastrophic,
} 
Thus, what I will do in this article is in line with narrative research on historywriting, but with the very important peculiarity that I have also co-authored the content of one of the inquiry reports I will analyse. A way to distance myself from this authorship (to the extent that this is possible) in order to be able to critically discuss its narration is to compare the reports from the Swedish Inquiry Commission (2006-2011) with those from the Irish Commission to Inquire into Child Abuse (CICA) - also known as the Ryan Commission (2000-2009) - and the Danish Godhavn Inquiry (2010-2011). In addition, comparison is a useful method for highlighting that despite country of origin, context of care or method of inquiry, the victims' testimonies as published in the reports are quite similar. What might differ, however, is how the reports make sense of the testimonies in the overall narrative and how a central concept such as 'truth' is employed. ${ }^{14}$

\section{Background and prerequisites of inquiries into historical institutional child abuse}

Still, while care leaver associations struggled for years to get the attention of governments, in many countries media coverage including the broadcasting of television documentaries has been one triggering dynamic in the establishment of inquiries into historical institutional child abuse or issuing official apologies. ${ }^{15}$ This is true for the inquiries conducted in Ireland, Sweden and Denmark.

In Ireland, the three-episode documentary States of Fear by the journalist Mary Raftery was broadcast on the national television channel RTÉ in April and May 1999. The documentary series told the history of Reformatory and Industrial schools in Ireland, in addition to exploring Schools for those with an intellectual and physical disability, many of which were run by Congregations of the Catholic Church. The care leavers interviewed in the documentary testified about systematic abuse and severe neglect. On the very same day the last episode was broadcast, then Taoiseach (Prime Minister) Bertie Ahern apologised to the victims of abuse within industrial and reformatory schools (11 May 1999). Within a year, the Irish Government had launched what subsequently came to be known as one of the world's

\footnotetext{
Inept, Self-Serving" Church? Re-examining Three Reports on Child Abuse in the Republic of Ireland' Journal of Progressive Human Services 24, no.1 (2013): 43-65; Niezen, Truth \& Indignation.

${ }^{14}$ Sköld, 'Historical Abuse-A Contemporary Issue', 6-7.

${ }^{15}$ Daly, Redressing Institutional Abuse of Children, 259-265.
} 
most extensive restoration processes for historical institutional child abuse. Both a financial redress scheme and a comprehensive inquiry (CICA) were launched. ${ }^{16}$

By the very way it was organised, comprised of two committees, CICA embodied the dual objective of investigating the past and recognising the victims. The Investigation Committee, had the task to '... receive evidence under oath and to make findings of fact upon the civil burden of proof.${ }^{17}$ Initially it had the power to identify and name perpetrators in public, a rule that came to be disputed by some of the religious congregations, and was legally challenged by the Christian Brothers, and eventually after some turbulence was abolished. ${ }^{18}$ The Confidential Committee was issued to listen to care leavers who wished to recount their experiences of abuse in a private, confidential (not public) forum; it eventually heard 1,090 witnesses. While scholars has characterised this as a therapeutic function ${ }^{19}$, a whole volume (445 pages) in the CICA's final report from 2009 is dedicated to the findings of the Confidential Committee, which evidences the significance of having these privately shared testimonies publicly narrated by the inquiry.

The storyline behind the establishment of the Swedish inquiry is similar to the Irish case. On November 27, 2005, the documentary Stulen barndom (Stolen childhood) was broadcast on national television. In this documentary, by journalist Tomas Kanger, six men told about the sexual abuse, physical violence and hard labour they had experienced at one boy's home in the 1950s and 60s. The programme attracted much attention, and within only a few days the Minister of Social Affairs assigned the Board of Health and Welfare with investigating whether similar abuse had also occurred at other institutions during the same period. This was a minor investigation that lasted only four months, and its investigators conducted no interviews. Still, many care leavers contacted the investigators to share their stories. When presenting their findings in March 2006, the investigators suggested that the

\footnotetext{
${ }^{16}$ Another extensive restoration process is the Indian Residential School Settlement Agreement, launched in Canada in 2007.

${ }^{17}$ Carol Brennan, 'Facing What Cannot be Changed: The Irish Experience of Confronting Institutional Child Abuse' Journal of Social Welfare \& Family Law 29, no. 3-4 (2007): 250; Eoin O'Sullivan, 'The Ryan Report: Reformatory and Industrial Schools and Twentieth Century Ireland', in Rosemary Meade and Fiona Dukelow (eds.), Defining Events: Power, Resistance and Identity in 21 st century Ireland (Manchester: Manchester University Press, 2015).

${ }^{18}$ Brennan, 'Facing What Cannot be Changed', 250, 255-257.

${ }^{19}$ Carol Brennan, 'Trials and Contestations: Ireland's Ryan Commission', in Johanna Sköld and Shurlee Swain (eds.), Apologies and the Legacy of Abuse of Children in 'Care' (Basingstoke: Palgrave Macmillan, 2015), 5569.
} 
government would establish a commission to document and interview care leavers about their experiences of abuse and neglect in institutions as well as foster homes. ${ }^{20}$

This marked the birth of the Commission to Inquire into Abuse and Neglect of Children in Institutions and Foster Homes, operating until September 2011. By its terms of reference, the inquiry was commissioned to identify and document abuse and neglect of children in municipal out-of-home care through interviews with care leavers and through archival research. The results were to be presented in a report with the dual mission to 'provide redress to the victims, and provide lessons for the future'. ${ }^{21}$ The government's instructions for the composition of the report mark the dual objective of investigating the past in order to inform the future, and aiming for justice by recognising the victims. The final report built upon interviews with 866 care leavers. The periods covered by the Swedish as well as the Irish inquiries were extensive: CICA covered 1914-2000, and the Swedish inquiry the 1920 s to the 2000 s. The inquiry was only restricted to investigating legally barred abuse. ${ }^{22}$

Turning to Denmark, it is evident that a television documentary was crucial there as well: Drengehjemmet (The boys' home), by journalist Rikke Skov. The documentary was broadcast on national television in February 2005, and raised the issue of whether children at the boys' orphanage Godhavn had been subjected to medical experiments. The documentary led to the establishment of a care leaver association of former Godhavn boys, who lobbied to influence the government to appoint a commission to examine the abuses at Godhavn in more detail. However, it proved difficult to convince the government, and nearly five years would pass before the Welfare Ministry allocated money for an inquiry in 2010. In contrast to Sweden and Ireland, the inquiry was not entrusted to a state-appointed commission; instead, researchers at the Welfare Museum in Svendborg were instructed to conduct an independent investigation. The investigation concentrated on the complaints raised by members of the Care Leaver Association of Godhavn's Boys, but eventually covered 19 of the 350 institutions operating in Denmark during the years 1945 to 1976. A total of 85 care leavers were interviewed. In addition, the investigators interviewed 14 staff members,

\footnotetext{
${ }^{20}$ Malin Arvidsson, 'Contextualizing Reparations Politics' in Johanna Sköld and Shurlee Swain (eds.), Apologies and the Legacy of Abuse of Children in 'Care' (Basingstoke: Palgrave Macmillan, 2015), 70-82. ${ }^{21}$ Dir 2006:75, Utredning om dokumentation och stöd till enskilda som utsatts för övergrepp och vanvård inom den sociala barnavården, June 212006.

${ }^{22}$ SOU 2011:61, Vanvård i social barnavård: slutrapport [final report from the Commission to Inquire into Abuse and Neglect of Children in Institutions and Foster Homes] (Stockholm: Fritzes 2011).
} 
examined medical records, and also called for a forensic blood analysis of a gymnastic horse that was mentioned as a site of abuse in one interview. ${ }^{23}$

The Danish inquiry hence differs from the Irish and Swedish ones in several aspects: the period covered, the number of care leavers heard, who commissioned the inquiry, and the methodology used. The Irish inquiry, in turn, was partly a public inquiry, which distinguishes it from the Danish and Swedish way of gathering testimonies. The Swedish inquiry is unique in its investigation of abuse and neglect in foster homes, whilst institutions were the focus of the Irish and Danish inquiries. ${ }^{24}$ Another difference is that while the Irish and Danish inquiries invited staff and care providers to witness, the Swedish inquiry focused exclusively on care leavers. ${ }^{25}$ In addition, there are several distinctions in the inquiries' aftermaths. The Irish CICA was preceded by an official apology, and parallel to the work of the inquiry a financial redress scheme was up and running (2002-2011). ${ }^{26}$ In Sweden an official apology was issued in November 2011 after the inquiry had released its final report, and subsequently a financial redress scheme was open 2013-2014. In Denmark, no official apology or financial redress has been issued to date. ${ }^{27}$

\section{The concept of truth}

The objective to investigate the past and identify the nature and extent of historical institutional child abuse brings to the table issues of responsibility, epistemology and methodology, whether explicit or implicit. What can be truthfully said about the past is a central feature of such discussions.

Truth is a central concept within the scholarship of both justice and history. A judicial truth is composed of factual evidence that is rhetorically narrated to convince the audience - the court. Thus, both facts and narration/rhetoric are essential for defining truth in this context. ${ }^{28}$ In historical research, the definition of truth is essential for determining the

\footnotetext{
${ }^{23}$ Maria Rytter, Godhavnsrapporten (Odense: Syddansk Universitestforlag, 2011).

${ }^{24}$ The confidential committee of the CICA did interview 24 foster care leavers, but the focus was on care leavers of institutions.

${ }^{25}$ The Swedish inquiry interviewed six former staff members, but the results from these interviews were not included in the reports. SOU 2011:61: 70.

${ }^{26}$ Residential Institutions Redress Board, Newsletter September 2015. Available at: http://www.rirb.ie/updates_article.asp?NID=139 (accessed 2016-04-04).

${ }^{27}$ Flemming Steen Pedersen, 'Minister: Forfærdeligt, men ingen undskyldning’ Berlingske 9 May 2015. Available at: http://www.b.dk/nationalt/minister-forfaerdeligt-men-ingen-undskyldning (accessed 2015-05-28).

${ }^{28}$ Katharina Sobota, 'Logos, Ethos, Pathos: A Quantitative Analysis on Arguments and Emotions in Law', in Retorik och rätt sett genom tio författares ögon, ed Kurt Johannesson (Uppsala: Iustus, 1994), 156, 169-171.
} 
epistemological position of the historian. During the 1990s the concept of truth spurred great debate within history, dating back to the late nineteenth century and the evolution of history as an empiricist and positivist science. ${ }^{29}$ If one claims, like the historicist Leopold von Ranke once did, that the objective of the historian is to tell 'what really happened', the epistemological position would be that 'the truth is out there', yet to be found through a variety of historical sources and source critical methods. Yet, if many historians today do not adhere to naïve empiricism, '[h]istorians like to think that no phenomenon disappears without leaving any traces. [...] it only takes the professional skills and imagination of the historian to figure out what they might be and where they might be found' ${ }^{30}$

When it comes to the history of children in out-of-home care, our archives are filled with traces from the activities involving these children. On a general level, there are many sources dealing with this group of children from the perspective of experts, social workers, headmasters and staff. On an individual level, however, the childhood mementos many people take for granted are unrecorded for many care leavers as they lack access to family photos, artwork, clothes and other traces of their lived childhoods. Their lived childhood must be narrated through memory instead; and, more importantly, the memories of care leavers and the archival records of the institutions or care providers seldom tell the same story. ${ }^{31}$ Taking on what I call an empiricist positivist epistemological position means that the historian, by rational methods and the use of a variety of sources, can arrive at fair accounts of what likely constitute true or false representations of the past. ${ }^{32}$ This position fits well with the investigative objective of truth and inquiry commissions.

Within a more postmodernist epistemological position, 'truth' is problematised in another way - there is no truth to be 'represented' or 'discovered', but rather only narration. ${ }^{33}$ This position has influenced the discussion of oral sources built on memories,

\footnotetext{
${ }^{29}$ See e.g. Joyce Oldham Appleby, Lynn Hunt and Margaret Jacob, Telling the Truth about History (New York: Norton, 1994); Christopher Behan McCullagh, The Truth of History (London: Routledge, 1998); Alun Munslow, Deconstructing History (London: Routledge, 1997).

${ }^{30}$ Marjatta Rahikainen and Susanna Fellman, 'On Historical Writing and Evidence', in Historical Knowledge: In Quest of Theory, Method and Evidence, eds. Susanna Fellman and Marjatta Rahikainen (Newcastle upon Tyne: Cambridge Scholars, 2012), 13.

${ }^{31}$ Jacqueline Z. Wilson and Frank Golding, 'Contested Memories: Caring about the Past - or Past Caring?', in Apologies and the Legacy of Abuse of Children in 'Care', eds. Johanna Sköld and Shurlee Swain (Basingstoke: Palgrave Macmillan, 2015), 33-36.

${ }^{32}$ McCullagh, The Truth of History, 307-308.

${ }^{33}$ Munslow, Deconstructing History. However, postmodern philosopher of history Frank Ankersmit has suggested that historians need to distinguish between 'narrative substances', which constitute interpretations of the past, and the 'referential statements' that are 'empirically verifiable claims about the world'. See Parkes, 'Postmodernism, Historical Denial, and History Education', 25-26.
} 
whereby the notion of what is remembered and told is a function of how a person's memory has been re-shaped and re-constructed over time, how the narrator understands and evaluates the historical event in the present, the relationship between the narrator and the interviewer, and so forth. Consequently, oral sources are not objective, which in a sense make them no different from written sources, even if this is not always acknowledged. ${ }^{34}$ However, the questions raised by many oral historians and postmodernist historians alike (What is remembered and how is the narrative of memory/history constructed?) is somewhat different from those asked by empiricist positivist historians (What really happened?); therefore, the basis for addressing a historical truth is different.

The concept of truth is crucial for truth commissions and inquiries into past atrocities; but, as Priscilla Hayner notes, 'official truth-seeking, it turns out, is a cumbersome and complicated affair'. ${ }^{35}$ The very object of both investigating what happened in the past and bringing about justice for victims suffering in the present imposes certain requirements on how the concept of truth can be used and understood. According to Beth Rushton, '...most truth commissions define truth not only as facts but also as testimony, so that each person's account becomes a truth in its own right' ${ }^{36}$ One example is how the influential South African Truth and Reconciliation Commission, operating 1995-2002, introduced distinctions between narrative truths corresponding to 'personal storytelling'; forensic (or factual) truths; social or dialogical truths referring to 'the process of collectively talking about the past'; and healing and restorative truth, which entails relating the 'facts' to present human relationships 'both amongst citizens and between the state and its citizens'. The binary distinction between narrative and forensic (factual) truths is currently also displayed in the Canadian Truth and Reconciliation Commission on Indian Residential Schools. ${ }^{37}$

However, in a postmodernist approach the very distinction between facts and testimonies, or factual and narrative truths, becomes somewhat problematic. In her analysis of the history debates that emerged after the 1997 publication of the Bringing Them Home report in Australia - an inquiry that addressed forced removals of aboriginal children - historian

\footnotetext{
${ }^{34}$ Alessandro Portelli, 'What Makes Oral History Different?', in The Oral History Reader, eds. Robert Perks and Alistair Thomson (London and New York: Routledge, 2006), 32-42.

${ }^{35}$ Priscilla B. Hayner, Unspeakable Truths: Transitional Justice and the Challenge of Truth Commissions (New York, Routledge, 2011), 5.

${ }^{36}$ Beth Rushton, 'Truth and Reconciliation? The Experience of Truth Commissions', Australian Journal of International Affairs 60, no. 1 (2006): 128.

${ }^{37}$ Rosemary Nagy, 'Truth, Reconciliation and Settler Denial: Specifying the Canada-South Africa Analogy'

Human Rights Review 13 (2012): 356-357; Niezen, Truth \& Indignation: 84.
} 
Rosanne Kennedy argues that facts and testimonies together consist of narratives, and therefore it is deeply problematic to regard facts as distinguished from the narrative form in which they appear and give rise to meaning. ${ }^{38}$ Testimonies, in turn, can be seen as interpretations of experiences. ${ }^{39}$ Consequently, Kennedy asks questions about how different compilations of testimonies from the so-called Stolen Generations are narrated according to style and interpretational frameworks, rather than what actually happened in the past. She concludes that the Report "presented witness testimony as documentary "evidence" - as an authentic and factual report of events - thereby downplaying issues of memory and construction'. ${ }^{40}$ This style 'was effective in producing empathy in readers, and in persuading a good proportion of the public of the need of reparation'. ${ }^{41}$ Yet, Kennedy is critical of this style and interpretative mode since it deprived the witnesses of the agency to interpret their own experiences; this was instead done by the experts within the inquiry. ${ }^{42}$

Other critical accounts of previous inquiries into institutional child abuse claim that victim narratives have been privileged over sources representing other perspectives on child welfare, resulting in biased truth claims. ${ }^{43}$ In contrast to Kennedy and others who dismiss any positivist approach to truth with the argument that testimonies 'should be read and analysed for their insights into how people involved in past events interpreted those events and their implications ${ }^{44}$, scholars like Mark Smith ask for a more empiricist prooftesting approach discussing the limited scope of victim narratives. In his criticism of the Scottish Government's Systematic Review of Historical Abuse, as well as the North Wales Tribunal of Inquiry, he called for contradictive stories (like positive memoirs) to be represented, victim testimonies to be analysed as constructed narratives rather than fact, an analysis of why people 'are saying what they say' 45 , records of residential institutions to be examined, and most importantly, for other voices than just the victims' to be heard, such as those of other care leavers and staff. ${ }^{46}$ Both sides agree that victim narratives are social

\footnotetext{
${ }^{38}$ Rosanne Kennedy, 'Stolen Generations Testimony', 509-510.

${ }^{39}$ Ibid., 514.

40 Ibid., 517.

${ }^{41}$ Ibid.

42 Ibid.

${ }^{43}$ Ron Brunton, 'Betraying the Victims: The Stolen Generations' Report' IPA Backgrounder vol. 10, no. 1 (1998): 1-24; Richard Webster, The Secret of Bryn Estyn: The Making of a Modern Witch Hunt (Oxford: The Orwell Press 2005); Mark Smith, 'Historical Abuse in Residential Child Care: An Alternative View' Practice: Social Work In Action 20, no. 1 (2008): 29-41; Mark Smith, 'Victim Narratives of Historical Abuse in Residential Child Care: Do We Really Know What We Think We Know?' Qualitative Social Work 9, no. 3 (2010): 303-320.

${ }^{44}$ Kennedy, 'Stolen Generations Testimony', 513; Nagy, 'Truth, Reconciliation and Settler Denial', 359.

${ }^{45}$ Smith, 'Historical Abuse in Residential Care', 34.

${ }^{46}$ Smith, 'Rethinking Residential Child Care', 311-312.
} 
constructs, and that inquiries have had a tendency to interpret them as fact, but they disagree on how narratives should be used in the context of inquiries.

This highlights some of the issues concerning investigating the past and at the same time recognising and aiming for justice for victims in relation to the concept of 'truth'. In light of this, I shall now demonstrate how 'truth' has been addressed in the Irish, Swedish and Danish inquiries into historical institutional child abuse.

\section{Truth-seeking - a process of investigation and recognition?}

If we merely look at how many times the word 'truth' is mentioned in the reports, it is used in 54 paragraphs in the five volumes of the CICA report, 13 paragraphs in the two reports of the Swedish inquiry, and eight paragraphs in the Danish Godhavn report. ${ }^{47}$ Given the prominent position the concept of truth holds in studies by truth commissions as well as historical research, it is interesting to note the word's infrequency in the reports. Most often, it appears in quotes from witnesses, either assuring investigators 'I'm telling you the truth' or describing how adults' demands on children to tell the truth were pretexts for abusive practices. In fact, the methodological complexity of truth is not addressed in any separate chapter in either the CICA or the Godhavn report; and in the Swedish inquiry the most prominent discussion about what truth might be appears in the epilogue, in addition to a chapter in the interim report devoted to source-critical accounts of memory. ${ }^{48}$

\section{The Irish CICA and the dual approach to truth}

The CICA report contains a few methodological reflections touching upon 'truth' in various chapters. In relation to the Swedish and Danish inquiries, the Irish CICA's Investigation Committee stands out since it held public oral hearings with both complainants (care leavers) and respondent church congregations (representing the alleged perpetrators). Consequently, the Investigation Committee had to balance between testimonies of complainants and

\footnotetext{
${ }^{47}$ The keywords I have used when browsing the reports are 'truth' for CICA, 'sanning' for the Swedish inquiry, and 'sand"' for the Godhavn report (excluding the word 'sandsynligtvis', which means 'likely' in English). Other keywords, such as reliability, credibility, and validity, could have rendered additional results. However, sample searches for these concepts in the reports demonstrate that they often appear in sections where 'truth' is also discussed.

${ }^{48}$ SOU 2009:99: chapter 10. The Godhavn report have one section on reliability, but it is less than half a page and consists mainly of a quote from the commissioner of the Norwegian national inquiry. Rytter,

Godhavnsrapporten, 19-20.
} 
respondents, which in turn had consequences for how 'truth' and related concepts like 'credibility' and 'reliability' were used.

In Volume 1, which addresses the Investigation Committee's reports on institutions, in the chapter on Artane - the largest industrial school, located outside Dublin - it is stated that 'evidence may be lacking in credibility or reliability for many reasons': memories can be affected by time, and witnesses can subconsciously exaggerate details or intentionally 'set out to give untruthful evidence'. The issue of untruthful evidence refers to the 'campaign for recognition and redress' - an engagement which, according to the responding congregations, devaluated the credibility of the complaining witnesses. ${ }^{49}$ It is important to bear in mind that television documentaries like 'States of Fear' attracted enormous public interest and, aside from a vast debate in the media, also spurred care leaver groups to meet and discuss their experiences as well as commit to the cause of recognition and redress. ${ }^{50}$ However, the Investigation Committee concluded that 'the fact that witnesses attended meetings or spoke to others was relevant in considering the value of their evidence, but was not a basis for rejecting it as necessarily unreliable'. ${ }^{51}$ Instead, the Investigation Committee stated that there were also grounds for questioning the reliability of evidence given by respondents: 'In some cases, the reliability of evidence could have been affected by the gravity of the allegations made against respondents themselves or against their colleagues; loyalty and affection for others, and for the Institution and the Congregation, may also have had a distorting influence on their testimony. ${ }^{52}$ In the end, some Brothers admitted to some of the allegations. ${ }^{53}$

The very methodology chosen by the Investigation Committee was to analyse documents of contemporary recorded incidents and assess the oral evidence 'by reference thereto, ${ }^{54}$, as well as consider each witness individually, and make no general rule 'either to accept or to reject the evidence of witnesses who may have been affected by factors tending to reduce the reliability of their evidence'. ${ }^{55}$ In the case of Artane, physical and sexual abuse was documented in the congregation's own records, letters of complaints to the Department of Education, police reports, and a report from 1962 by a former chaplain, who also testified

\footnotetext{
${ }^{49}$ CICA vol. 1: 7.51.

${ }^{50}$ CICA, vol. 1: 5.32-5.33.

${ }^{51}$ CICA, vol. 1: 7.51 .

${ }^{52}$ CICA, vol. 1: 7.53.

${ }^{53}$ See for example CICA, vol. 1: 7.89-7.91.

${ }^{54}$ CICA, vol. 1: 5.39, 7.54.

${ }^{55}$ CICA, vol. 1: 7.52 .
} 
before the Committee. His testimony confirmed much of what the complainants had told the Committee about physical abuse. ${ }^{56}$

Written documentation (altogether, more than a million documents were analysed $)^{57}$ as well as third-party witnesses seem to have been crucial for the conclusions the Investigation Committee was able to draw from the myriad of sometimes conflicting oral testimonies of complainants and respondents. Written documentation was scrutinised and then compared to oral sources. ${ }^{58}$ This could be seen as an expression of a positivist or legal approach to truth, in which a variety of historical sources and source-critical methods are to bring us closer to 'what happened'.

From a childhood historian point of view, one could ask how the very experience of being a child within these systems of abuse was recognised by the Investigation Committee. The reports on each institution are structured around the alleged abuse and the alleged perpetrators, and are dealt with case by case in a more or less judicial manner. This means that the events or acts, for example the severe punishment that led to a boy's arm being broken $^{59}$, are focused on rather than individual victims' narration of their total experience of being at that particular institution. Still, the events and the thorough investigation of them reveal important information about the everyday life of the children who lived at those institutions.

It is interesting to note that the report from the Confidential Committee (Volume 3) based on interviews with 1,090 witnesses - most identified as victims - does not address the methodological complexity of 'truth' at all. However, this has to do with the Committee's therapeutic functions and its purpose 'to provide an opportunity for abuse victims who wish to tell of the abuse suffered by them but who do not wish to have that abuse inquired into' ${ }^{60}$ The Confidential Committee was to offer recognition to victims, whereas the Investigation Committee was assigned to hear people '... whose accounts it considers will provide it with the greatest possibility of arriving at the truth of what occurred' ${ }^{61}$

Yet, the Confidential Committee's way of narrating its findings, through statistics of witnesses reporting similar experiences, serves to convey to the reader the witnesses' accuracy. Chapters on witnesses' accounts of abuse and neglect are structured

\footnotetext{
${ }^{56}$ CICA, vol. 1: 7.233-7.243; 7.312-7.548.

${ }^{57}$ CICA, vol. 1: 5.03

${ }^{58}$ CICA, vol. 1: 7.49.

${ }^{59}$ CICA, vol. 1: 7.112-7.137.

${ }^{60}$ CICA, vol. 3: Appendix 1, 'Commission to Inquire into Child Abuse Bill 2000', section 15.

${ }^{61}$ CICA, vol. 3: Appendix 2, 'Commission to Inquire into Child Abuse (Amendment) Bill 2005', section 7.
} 
around numbers of reports, supported by illustrative quotes from witnesses. For example, in the chapter on abuse reported by female witnesses, the Committee states that 'there were 383 reports of physical abuse given in evidence to the Committee by 374 witnesses (99\%) involving 39 schools [...] Three (3) schools were collectively the subject 144 reports...' ${ }^{62}$ I argue that numbers presented in this way possess a certain persuasive power, in which the quantification of individuals' qualitative testimonies suggests a certain degree of accuracy. Through the mediation of numbers, singular narratives are transformed into a representative account of a traumatic past.

I want to emphasise that the reason for stressing numbers' persuasive power has no intention of questioning the witnesses' narratives or Committee's results, but rather of highlighting the logic that truth commissions and inquiries dealing with past atrocities write for audiences who need to be made indignant on behalf of the victims in order for the victims to be fully recognised. ${ }^{63}$ It is especially important to affect politicians, who have the power to decide on further actions of redress. The quote above, stating that $99 \%$ of the female witnesses reported physical abuse, has the potential to elicit an emotional reaction in the reader. In this way, statistics serve as a rhetorical tool.

\section{The Swedish Inquiry and the ambivalent approach to truth}

The rhetoric of statistics can be observed in the responses to the interim report of the Swedish inquiry commission published in 2010, building on testimonies from 404 witnesses. It stated, for example, that 'more than half of all interviewees have told of sexual abuse. A larger proportion of women ( 61 percent) than men (42 percent) report that they have been sexually abused' ${ }^{64}$

The Minister of the Children and the Elderly labelled the historical abuse presented in the report as 'a dark chapter in our history', and the response was to establish yet another commission with the purpose to investigate and make suggestions for reparations and redress. ${ }^{65}$ The interim report from the Swedish inquiry followed the structure of the Irish Confidential Committee's report in great detail. ${ }^{66}$ Similar categories of abuse were identified, and each category was depicted according to the number of witnesses reporting abuse and

\footnotetext{
${ }^{62}$ CICA, vol. 3: 9.01.

${ }^{63}$ Niezen, Truth \& Indignation, 14-17.

${ }^{64}$ SOU 2009:99: 233.

${ }^{65}$ Malin Arvidsson, 'Ett mörkt kapitel i vår historia?’ Locus 2 (2011): 26.

${ }^{66}$ The impetus from international counterparts when establishing inquiries and redress schemes is highlighted in Johanna Sköld, 'Apology Politics: Transnational Features', in Apologies and the Legacy of Abuse of Children in 'Care’, eds. Johanna Sköld and Shurlee Swain (Basingstoke: Palgrave Macmillan, 2015), 13-26.
} 
illustrated with quotes from the interviews. Both inquiries used databases, with the great number of testimonies rationalised into classified categories of abuse. But since databases that quantify qualitative data tend to delimit the scope of inquiry, this method can result in 'a contextual logical positivism, where one focuses on acts, names of perpetrators, and names of victims, but does not ask why and how' ${ }^{67}$

Aside from using statistics and illustrative quotes, in its final report the Swedish inquiry employed other measures to represent testimonies, for example publishing three narratives written by care leavers. These narratives, though chosen by us, were not processed through the investigators' questions, the narrations or the database, but rather represented an approach that, according to Kennedy, 'provides witnesses with the resources to interpret their experience' ${ }^{68}$ Additionally, empiricist methods were employed - for instance comparing oral testimonies with archival documentation; identifying and comparing testimonies about the same institutions or foster homes; investigating cases that had led to court convictions - and relating the results to findings by inquiries abroad. In the epilogue to the final report, the commissioner Mr Göran Johansson discusses these measures and highlights how concepts of 'credibility' and 'truth' have been essential for the victims themselves.

'It has never been the commission's task to evaluate or assess the credibility of the stories that have come to our knowledge, no matter how "improbable" they've been. Nevertheless, I now note that the credibility aspect has run as a common thread through the investigation. [...] The interviewees have in different ways alerted us to how preoccupied they have been with dealing with their memories from a credibility perspective. [...] The interviewees have wanted to make sure they are believed, that no one should think they're lying or making things up. Some have wanted to validate their testimonies with "support evidence" such as photographs, letters and third-party witnesses.

On countless occasions we've had to reassure interviewees that our job is not to determine what is true or not. That we do not have the task to question or evaluate the veracity of what they tell us. Despite this, when confronted with horrific, incomprehensible "improbable" stories and vicious

\footnotetext{
${ }^{67}$ Janis Grobbelar cited in Hayner, Unspeakable Truths, 80.

${ }^{68}$ Kennedy, 'Stolen Generations Testimony', 516.
} 
contexts, we have raised the question: Can this really be true, is this possible, how can anyone treat a child this way?' ${ }^{69}$

This quote illustrates how complex the situation is for investigators and care leavers alike. In order to be recognised, care leavers need to be believed; and in order to be believed the investigators and, subsequently the reports' audiences, have to overcome the haunting question 'can this really be true?' No matter how much one sympathises with Kennedy's position that testimonies shouldn't be scrutinized to proof-testing, but rather be analysed as insights to experiences, for some people, as observed by the Swedish commissioner, this is not the primary understanding of recognition in the context of truth commissions and inquiries. It seems that there are persistent expectations on truth commissions and inquiries to achieve something more, corresponding to their investigative objective - that 'narrative truths' of care leavers should be supported with records of 'forensic truths' of what happened..$^{70}$ Consequently, a positivist empiricist approach to truth is called upon by the same token as a postmodern and constructionist concept such as the 'narrative truth' is displayed. Two epistemologically conflicting approaches to truth are hence expected to unite within the work of an inquiry. The Swedish commissioner describes how he and we (the investigators) had to balance between documenting the narrative truths and taking seriously the demands of validation and credibility:

'It would be naive to think that all that we've been told would be consistent with reality to the very last letter. We cannot know for sure, due to the simple fact that we weren't there when it happened. Whatever my standpoint is, it is a result of active choices; from which perspective I choose to consider reality and how I choose to interpret it. Now, with the work of the inquiry in hindsight and when reading this report, I argue that it is explicit, but perhaps more or less "between the lines", how we dealt with the credibility themes we were confronted with. ${ }^{71}$

This is an interesting quote from a commissioner, admitting that the truth as a past verified reality is just a construction, while what remains are active normative choices regarding whose perspective to consider and how to interpret it. But it is also mysteriously unclear, what

\footnotetext{
${ }^{69}$ SOU 2011:61: 309.

${ }^{70}$ Nagy, 'Truth, Reconciliation and Settler Denial', 356; Niezen, Truth \& Indignation, 84.

${ }^{71}$ SOU 2011:61: 311 .
} 
is to be read 'between the lines'? Actually, this refers to the results of the empiricist case studies the inquiry undertook when comparing 140 witnesses' oral testimonies to their archival case files, concluding that '... the possibility of using the files to verify or prove false claims of abuse or neglect by those interviewed was extremely limited'. ${ }^{72}$ The comparison demonstrated, amongst many things, that case files and oral testimonies represent conflicting perspectives on the same story, that the quality and availability of case files varied greatly, and that authorities had been cautious to explicitly note any suspicion of abuse or neglect. ${ }^{73}$ In this case study, the empiricist method led to a dismissal of empiricist and positivist approaches to truth, at least in the context of singular cases.

In another case study, we compared reports of abuse from different witnesses who had resided in the same location. It is important to remember that the Swedish inquiry did not invite witnesses from named institutions like many inquiries abroad did. The witnesses appeared before the inquiry independently, and many told of experiences at several locations. The inquiry concluded that it had received reports of abuse from at least two witnesses at 119 institutions, and 35 foster homes were similarly identified. Three institutions, where abuse was confirmed by more than 15 witnesses, were explored in depth. The results of this case study showed that witnesses who had resided in the same location often gave similar descriptions of abuse on a general level, despite some differences in how the extent of the abuse was narrated. One example is how three witnesses who had resided at the same foster home on a farm during 1960s narrated experiences of labour. One witness did admit that the children had to help out a great deal on the farm, but he did not interpret this as forced labour or abuse. The second witness also confirmed a certain amount of work, but described it as seasonal. The third witness narrated his experience of work as forced labour with dangerous elements, and regarded it as part of the abuse at the foster home. The inquiry made no further analysis of this result, but stressed that the conformities were greater for witnesses who had resided in institutions than in foster homes. ${ }^{74}$

This case study's approach is similar to that of the Irish Investigation Committee and the Danish inquiry, in which the structures and events at certain institutions were focused on by compiling narratives from several independent sources/witnesses. To summarise, the

\footnotetext{
${ }^{72}$ SOU 2011:61: 51.

${ }^{73}$ This case study is presented in English in Johanna Sköld, Emma Foberg \& Johanna Hedström, 'Conflicting or Complementing narratives? Interviewees' Stories Compared to Their Documentary Records in the Swedish Commission to Inquire into Child Abuse and Neglect in Institutions and Foster Homes' Archives and Manuscripts 40, no. 1 (2012):15-28.

${ }^{74}$ SOU 2011:61: 47-49; 199-219.
} 
Swedish inquiry used several empiricist methods to transcend numbers of singular narrative truths to a general positivist account of 'how it likely was', illustrated by the commissioner's final standpoint: 'I am now quite confidently leaning towards a standpoint that it most likely can be assumed that severe abuse has taken place in about the same way as we have been told. ${ }^{75}$

\section{The Danish Godhavn Inquiry: a combination of a narrative and forensic approach to truth}

The Danish Godhavn report, in turn, presents no coherent discussion around the concept of truth, but related issues are reflected in the various case studies. The outline of the Godhavn report is structured around the institutions examined: first a thorough investigation of the boys' home Godhavn is presented throughout both interviews and medical records, and then shorter descriptions of further 18 children's homes. The Danish inquiry treated witnesses' testimonies in a similar vein as the Swedish inquiry and the Irish Confidential Committee; the investigators did not 'question the truthfulness of the witnesses' memories of their childhood in orphanages'. ${ }^{76}$ However, the Danish inquiry marked its difference from the Swedish one by stressing a 'narrative approach' in contrast to the Swedish statistical focus on abuse. ${ }^{77}$ The narrative approach meant that several oral testimonies about a specific institution were compiled into a master narrative on that institution, but as long as the anonymity could be safeguarded, the Danish investigators asked about events and situations previous witnesses had revealed, in order to 'illuminate an event or situation from several perspectives'. ${ }^{78}$ The investigators especially expressed an interest in clarifying whether the description by care leavers was recognised by former staff who also witnessed before the inquiry. The narrative approach can be read as an instrument for balancing testimonies from care leavers and staff, but in most cases the testimonies from staff supported those from care leavers as presented in the report.

A specific focus in the Danish inquiry concerns the medical treatment at Godhavn, as the TV documentary by Rikke Skov had claimed that illegal medical experiments on children had been conducted there. It was also stressed that the medical records had disappeared; however, the Danish inquiry found the medical records in a wooden

\footnotetext{
${ }^{75}$ SOU 2011:61: 311.

${ }^{76}$ Rytter, Godhavnsrapporten, 32.

${ }^{77}$ Ibid., 34. At the time the Danish Godhavn report was written (2010-2011), the final report from the Swedish inquiry containing the different case studies described above was not yet published. The Swedish interim report focused on categories of abuse narrated through statistics and illustrative quotes.

${ }^{78}$ Ibid., 32.
} 
box in the basement at Godhavn, which still operates as an institution. ${ }^{79}$ The medical records were analysed and contextualised by the inquiry, concluding that there was no evidence of illegal medical experiments at Godhavn in order to contribute to scientific knowledge. However, the school's psychiatrist did expose individual children to experimental treatment whereby he tried one preparation after the other in order to treat enuresis and some other symptoms. Some of the drugs he prescribed had not been previously tested for use in children, and the inquiry concluded that he "may have been the first psychiatrist in Denmark to use drastic antipsychotics on children' ${ }^{80}$ This case study set out to answer an empiricist question of whether or not illegal medical experiments had taken place, but it achieved a more nuanced understanding of psychiatric treatment at children's homes during the post-war period. In doing so, the inquiry presented a different narrative than the TV documentary.

Related to the concept of truth is the issue of representativity, which is discussed with reference to the 18 institutions where the inquiry heard evidence from only a few witnesses. The investigators consulted the commissioner of the Norwegian national inquiry: 'Our data showed that it was never a case of many children being exposed to abuse at institutions where abuse was documented. There was usually only one victim, possibly two. [...] just one or a few children were "selected" victims, and this is evident even for the worst institutions. ${ }^{81}$ This quote is left without interpretation by the Danish investigators in the report, but seems to suggest that testimonies of historical institutional abuse can never be expected to be representative in any statistical sense of the word, since abuse does not happen to every child residing in the same institution. In this context, the quote from the Norwegian commissioner served to justify presentations of abuse at institutions based on only a few witnesses.

A final case study concerned the forensic blood analysis of a gymnastic horse belonging to one boys' home. One witness told the inquiry how he and other boys used to be beaten by the headmaster with a rope until they bled, while leaning over the gymnastic horse. Given that the inquiry was undertaken by a museum, the investigators were attentive to the symbolic value of artifacts, and in retrospect they have described how they set out to find the gymnastic horse:

\footnotetext{
${ }^{79}$ Ibid., 36, 134.

${ }^{80}$ Ibid., 177. The quote is taken from an article in English on the Godhavn inquiry: Maria Rytter and Jacob Knage Rasmussen, 'Denmark: The Godhavn Inquiry' in Apologies and the Legacy of Abuse of Children in 'Care', eds. Johanna Sköld and Shurlee Swain (Basingstoke: Palgrave Macmillan, 2015), 101.

${ }^{81}$ Rytter, Godhavnsrapporten, 181.
} 
'We realized [...] the potential of this find and the impact it could have, not only for the museum but for many of the abused children from children's homes, as a symbol, evidence, and proof of the abuse and illegal punishment that had taken place in such institutions in the 1960s. Children in care are not used to being believed when they talk about their childhood sufferings, and this has led to serious existential problems such as loneliness, feelings of inferiority, and isolation. The survival of this type of evidence could be the "smoking gun" that so many had been longing for." 82

For the same reason as the Swedish commissioner argued for empiricist approaches in order to take seriously victims' demands for validation and credibility, the Danish investigators looked for something outside the oral testimonies themselves, in order to find a 'symbol, evidence, and proof' that serious abuse 'had taken place'. The forensic blood analysis conducted by the National Forensic Department in Denmark showed that the gymnastic horse was covered in a number of blood stains, and the police technician could tell that 'the size of the stains proved that the boys had been beaten with great force'. ${ }^{83}$ Again, it is demonstrated that investigators interpret the victims' urge for recognition as an act of convincing public audiences. Beyond telling one's story, recognition is about being believed.

\section{Conclusion}

Investigating and recognising historical institutional abuse is a complex act of balancing between positivist empiricist and postmodern constructivist approaches to what can be truthfully said about the past. On the contrary to studies that have criticised previous inquiries for privileging victim narratives over sources representing other perspectives, the comparison of the Irish, Swedish and Danish inquiries clearly demonstrates that victim narratives have been challenged by and complemented with other voices and materials, and the case studies undertaken have used a variety of empiricist methods. One of these critics, Mark Smith, holds as his main argument that victim testimonies need to be analysed as constructed narratives rather than facts, and that a tendency to not do so has created a biased master narrative of historical institutional abuse, at least in the UK. Amongst many things he has called for positive memories to be represented, voices other than just the victims' to be heard, and an

\footnotetext{
${ }^{82}$ Maria Rytter and Jacob Knage Rasmussen, ‘A Great Find: Turning the World Upside Down' Journal of the History of Childhood and Youth 8, no. 1 (2015): 11-12.

${ }^{83}$ Ibid., 13.
} 
analysis of why people 'are saying what they say' - for instance, suggesting that financial compensation 'is a significant determinant in many of the historical abuse allegations that are made' ${ }^{84}$

Positive experiences were devoted a chapter in the report of the Confidential Committee by the Irish $\mathrm{CICA}^{85}$; but given the focus on abuse and neglect, this subject is not elaborated on in either the Danish or Swedish inquiry. Of course this creates a certain kind of history narrative of child welfare institutions and out-of-home care, and bears with it an ethical risk that care leavers not identifying with the victim narrative - who rather have happy memories of their childhood in an institution or foster home - still 'have to share the accompanying burden of victimhood' ${ }^{86}$ Therefore, historical research taking a broader approach to care leavers' narratives than exclusively focusing on abuse and neglect has much to contribute. ${ }^{87}$ Nevertheless, as Shurlee Swain, Leonie Sheedy and Cate O'Neill have argued, before similar inquiries were issued in Australia, care leavers now identifying themselves as Forgotten Australians 'were confronted by a cultural silence which denied them the language, concepts, and accepted narratives within which to construct and narrate their own experiences'. ${ }^{88}$ Hence, inquiries have the potential to both convey and silence narratives of care leavers.

The suspicion, highlighted by Smith, that care leavers testify about abuse for the sake of financial compensation, cannot be supported by the contexts in which the Irish, Swedish and Danish inquiries came about. In Ireland, the Residential Institutions Redress Board operated in parallel to CICA - witnessing before the inquiry did not impact the outcome for an individual at the Redress Board. In Sweden and Denmark, no commitments of financial compensation were mediated by politicians at the outset of the inquiries; the Swedish inquiry was even restricted from discussing financial compensation in its terms of reference. ${ }^{89}$ However, the demand for recognition has included expectations of financial compensation amongst some care leavers. ${ }^{90}$ Yet, it is completely different to argue that

\footnotetext{
${ }^{84}$ Smith, 'Historical Abuse in Residential Care', 34.

${ }^{85}$ CICA vol. 3: chapter 10. See also CICA vol. 3: 254, 290-291, 319, 385.

${ }^{86}$ Kjersti Ericsson, 'Victim Capital and the Language of Money: The Norwegian Process of Inquiries and Apologies' Journal of the History of Childhood and Youth vol. 8, no. 1 (2015): 134.

${ }^{87}$ The Journal of the History of Childhood and Youth's special issue on experiences of children in out-of-home care 8, no. 1 (2015) demonstrates how historians can explore narratives of care leavers in many different ways. ${ }^{88}$ Shurlee Swain, Leonie Sheedy and Cate O'Neill, 'Responding to "Forgotten Australians": Historians and the Legacy of Out-of-home "care"” Journal of Australian Studies 36, no.1 (2012): 25.

${ }^{89}$ Dir 2006:75, Utredning om dokumentation och stöd till enskilda som utsatts för övergrepp och vanvård inom den sociala barnavården, June 212006.

${ }^{90}$ Ericsson, 'Victim, Capital and the Language of Money', 127.
} 
financial compensation is 'determinant' for care leavers to step forward and tell their story; they actually all did this without any promise of award and despite the exceptional personal risks that are connected to witnessing of abuse. Rather, such notions say something about the general scepticism many care leavers are confronted with when they tell stories of abuse and neglect. This scepticism is also reflected in what the investigators interpreted as care leavers' fear of not being believed. This, in turn, had consequences for which methods the inquiries used to investigate the past.

Still, while the aim has not been to dispute the testimony of care leavers, the objective to recognise and seek justice for the victims seems to require that issues of reliability, validity and credibility be taken seriously. The objective of the Irish Investigation Committee of investigating abuse, is then just another aspect of recognition aside from letting care leavers tell their 'truths'. This is related to the importance of addressing and convincing conflicting public audiences about the accuracy of narratives of child abuse that go against the general public's genuine beliefs and (self-)identities related to the narratives of a 'benign church', 'benign state', etc., which is a prerequisite for the recognition of groups or individuals who have suffered from injustice. ${ }^{91}$

We may ask whether such an aim is impossible to achieve without employing empiricist positivist approaches to 'what really happened'; or whether publically available narrations, whereby the care leavers themselves - perhaps in collaboration with historians or other professionals - represent and interpret their own conflicting stories, have the potential to emerge as truthful accounts that both emancipate care leavers and convince society at large to recognise the consequences and suffering of historical institutional abuse present in our societies. I am not inclined to answer this question, but the results from this comparative study suggest that inquiries, rightfully or not, have approached the truth about historical institutional abuse for the better part through empiricist positivist methods of inquiry privileging the experts' (investigators') interpretations. However, this approach has not been without ambivalence, and there are examples of more constructivist and memory-representing approaches as well. This remark is compatible with how Onur Bakiner have described the narrative strategies of truth commissions in general. A commission's legitimacy within the larger society is not a given, it is performed in an act of balancing persuasion aimed at those 'political and social actors who establish and advocate them, and those who question their

\footnotetext{
${ }^{91}$ Janna Thompson, 'Reparative Claims and Theories of Justice' in Historical Justice and Memory, eds. Klaus Neumann and Janna Thompson (Madison \& London: University of Wisconsin Press, 2015), 49-50.
} 
accuracy, usefulness and legitimacy.' As a result, commissions 'constantly negotiate the boundaries between legal-forensic and narrative-historical notions of truth to validate their claim to truth (an authorative account of the past) and memory (a shared account of the past). ${ }^{, 92}$

Critically analysing inquiries and their narrations of the history of out-of-home care is a highly ambivalent operation. On the one hand, a deconstructionist approach may reveal something about hidden agendas in narrativisation; but on the other, as Berber Bevernage et al. have argued, it has a tendency to ignore the content and the "practical consequences of writing history'. They stress that the critical potential in philosophy of history demands that we 'go beyond narrativisation as such' and take 'seriously the ethical issues that arise from memory'. ${ }^{93}$

But what is an ethical response in relation to narratives on historical institutional abuse? Perhaps it is as Shurlee Swain et al. have argued, that 'while historians may disagree with elements of individual survivor narratives, they write with respect for such accounts, remembering at all times that their histories are grounded in the lives of real people many of whom suffered and continue to suffer real pain and are now looking to have those experiences validated'. ${ }^{94}$ At their best, truth commissions and inquiries produce such inclusionary and complex historical narratives. ${ }^{95}$ This is similar to the call from historian Jorma Kalela for historians to engage in participatory historical culture. He holds as one of his main arguments that an ethical dimension of the historian's work is to provide 'the people addressed with a realistic opportunity of evaluating results achieved.' Just like truth commissions and inquiries, the historian cannot claim to be neutral, but Kalela maintains that the historian's task is not to 'provide society with a moral compass'. Rather, the historian has to seriously cope with his/her own biases in order to enhance understandings of the past. ${ }^{96} \mathrm{~A}$ common task for historians aimed at participatory historical culture and truth commissions or inquiries alike is to influence affected and inflected audiences of the soundness and fairness of the historical account. In this respect, truth commissions and inquires can learn from historians' ethical objective to scrutinize their biases while aiming at justified interpretations of the people and

\footnotetext{
${ }^{92}$ Bakiner, 'One Truth among Others?', 346, 356.

${ }^{93}$ Berber Bevernage, Broos Delanote, Anton Froeyman and Kenan Van de Mieroop, 'Introduction: The Future of the Theory and Philosophy of History' Journal of the Philosophy of History 8 (2014): 143.

${ }^{94}$ Swain, Sheedy and O’Neill, 'Responding to "Forgotten Australians", 25.

${ }^{95}$ Bakiner, 'One Truth among Others?', 356.

${ }^{96}$ Jorma Kalela, Making History - The Historian and Uses of the Past (Basingstoke: Palgrave Macmillan, 2012): 102-108.
} 
events of the past. By contrast, historians can learn from the pluralistic approaches to methodology and epistemology that truth commissions and inquiries employ in order to perform their legitimacy and balance between the dual objective of investigating the past and recognizing the historical subjects (the victims). 